\title{
The restoration of the Oratory of the Partal Palace in the Alhambra of Granada, Grand Prix Europa Nostra 2019
}

\author{
Federico Wulff Barreiro(1)
}

\begin{abstract}
This research focuses on the latest restoration of the Oratory of the Partal Palace (2013-2017), a 14th-century palatine mosque in the Alhambra, one of the most important UNESCO-listed World Heritage Sites of Spain. This restoration was awarded the Europa Nostra Grand Prix 2019, the most prestigious European heritage award, promoted by the European Commission. The restoration revealed original inscriptions, decorative elements and constructive solutions from the Nasrid period that had been unknown to date. The interpretation of these discoveries enabled a deeper understanding of Nasrid carpentry techniques as distinctive from their Christianmudéjar counterparts. The dendrochronology tests of the original decorated timber framework covering the prayer space consistently dated its timber elements as having been cut during the autumn/winter of 1332-1333. This would prove that the Oratory had been conceived of and its construction initiated on a date earlier than its widely accepted attribution to Yusuf I (1333-1355), most likely during the rule of the earlier sultan Ismai'l I (1314-1325), who had already made several interventions in the Partal Palace. The improved legibility of the last two 1846 and 1930 historical restorations has enabled the interpretation of the Oratory of the Partal Palace as a compendium of Spanish heritage preservation approaches over the last 180 years.
\end{abstract}

Keywords: Alhambra, Nasrid, Carpentry, Partal Palace, Timber framework, Mudéjar

\section{Introduction}

The Alhambra palatine complex, a UNESCO-listed World Heritage Site since $1984,{ }^{1}$ is considered the most important heritage site of Spain and is the most visited. It is one of the best-preserved medieval Islamic palatine complexes worldwide and the most important heritage site built in the Iberian Peninsula during the Islamic period (711-1492). It has been interpreted as a palimpsest of the multiple intercultural interactions during medieval Muslim and Christian rules, intimately connected to the exceptional values of its natural landscape. Its

${ }^{1}$ https://whc.unesco.org/en/list/314/ Accessed April 12, 2019

Correspondence: WulffF@cardiff.ac.uk

Welsh School of Architecture, Cardiff University, Bute Building, King Edward VII Avenue, Cardiff CF10 3NB, UK

\section{Springer Open}

construction was initiated in the mid-13th century under the first emir of the Kingdom of Granada, Muhammad Ibn al-Ahmar (1195-1273). This emir founded the Nasrid dynasty that ruled the Kingdom of Granada from 1238 until 1492. It was the last Muslim kingdom on the Iberian Peninsula to be conquered by Christians, which occurred in 1492, the same year as the discovery of America by Christopher Columbus. The Alhambra complex includes a series of royal palaces and a complex system of towers, defensive walls and military fortresses, together with water infrastructure and a rich variety of gardens supporting the life of the royal court of the Nasrid dynasty. The Alhambra was mainly completed a century later during the reigns of the sultans Yusuf I (1333-1354) and his son Muhammad V (1354-

(c) The Author(s). 2021 Open Access This article is licensed under a Creative Commons Attribution 4.0 International License, which permits use, sharing, adaptation, distribution and reproduction in any medium or format, as long as you give appropriate credit to the original author(s) and the source, provide a link to the Creative Commons licence, and indicate if changes were made. The images or other third party material in this article are included in the article's Creative Commons licence, unless indicated otherwise in a credit line to the material. If material is not included in the article's Creative Commons licence and your intended use is not permitted by statutory regulation or exceeds the permitted use, you will need to obtain permission directly from the copyright holder. To view a copy of this licence, visit http://creativecommons.org/licenses/by/4.0/. 
1359/1362-1391), the two most well-known Nasrid sultans of the dynasty (Fernández-Puertas 1997).

The Partal Palace, attributed to the Nasrid emir Muhammad III (1302-1309) with later interventions during the rule of the sultan Isma'il I (1314-1325), is the earliest surviving structure amongst the Nasrid royal palaces that have articulated the Alhambra complex (Torres Balbás 1959, 402).

The Partal Palace includes the Ladies' Tower (Torre de las Damas), a portico decorated with interlaced sebka motifs and deeply influenced in its conception by the former Almohad dynasty architecture, and a rectangular water pond. On its north side, the Partal Palace faces the Albayzín, one of the best-preserved medieval Nasrid neighbourhoods in Granada, also listed as a UNESCO World Heritage Site (Fig. 1). It is closely related to the most renowned and bestpreserved Nasrid palaces of the Alhambra, built on successive dates: the Palace of Comares attributed to Yusuf I and the Palace of the Lions, attributed to his son Muhammad V (Fig. 2).

\section{The Oratory of the Partal Palace}

The Oratory of the Partal Palace is a private palatine mosque built for the exclusive use of the Nasrid sul$\tan$ that has been widely attributed to Yusuf I (13331354).

Together with the Arabic houses of the Partal Palace and the House of Astasio de Bracamonte, they form a set of buildings that constituted an essential part of the daily life of the sultan's medieval court. From the perspective of its religious use and its decorative programme, the Oratory could be considered the most important building in this palatine complex (Fig. 3).

The House of Astasio de Bracamonte is a building adjacent to the Oratory's south-eastern wall that was built earlier than the palatine mosque, although its second floor was constructed during a later period (Torres Balbás 1945: 443, 448). In 1550, it was given by Emperor Charles V to Astasio de Bracamonte, the squire of the Governor of the Alhambra, the Count of Tendilla. The Oratory and the House of Astasio are covered by two four-sloped roofs of slightly different heights, with a difficult encounter that has produced several structural and constructive pathologies, addressed during the 20132017 restoration (Fig. 4).

Access to the Oratory is obtained by a staircase built alongside the north-eastern defensive walls of the Alhambra, built between the end of the 13th century and the beginning of the 14th century.

Both buildings sit on an earlier tower $15 \mathrm{~m}$. high that formed part of these defensive walls.

The plan of the Oratory has a reduced rectangular proportion of $4.16 \mathrm{~m}$. long by $3 \mathrm{~m}$. wide (Fig. 5). The north-western access faces the mihrab, the sacred space where the Muslim worshippers directed their prayers, located on the south-eastern partition wall shared with the House of Astasio. Wide openings including twin windows divided by columns are located on its northeastern facade facing the Albayzín and on its southwestern facade over the gardens of the Partal Palace.

The House of Astasio, originally a Nasrid house associated with daily life in the Partal Palace, was conceived independently from the mosque and hence has a separate entrance from the Partal gardens. Another

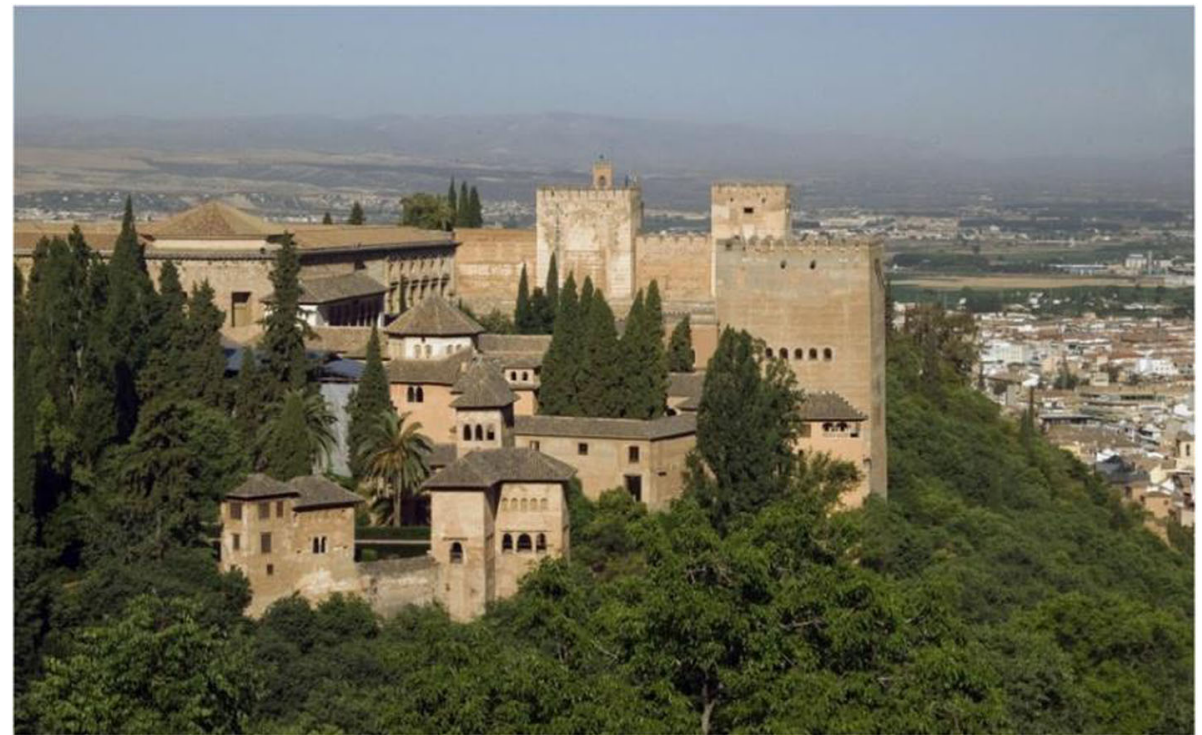

Fig. 1 The Oratory and the House of Astasio, part of the Nasrid royal palaces articulating the Alhambra, in a view from 2020 (Source: the author) 


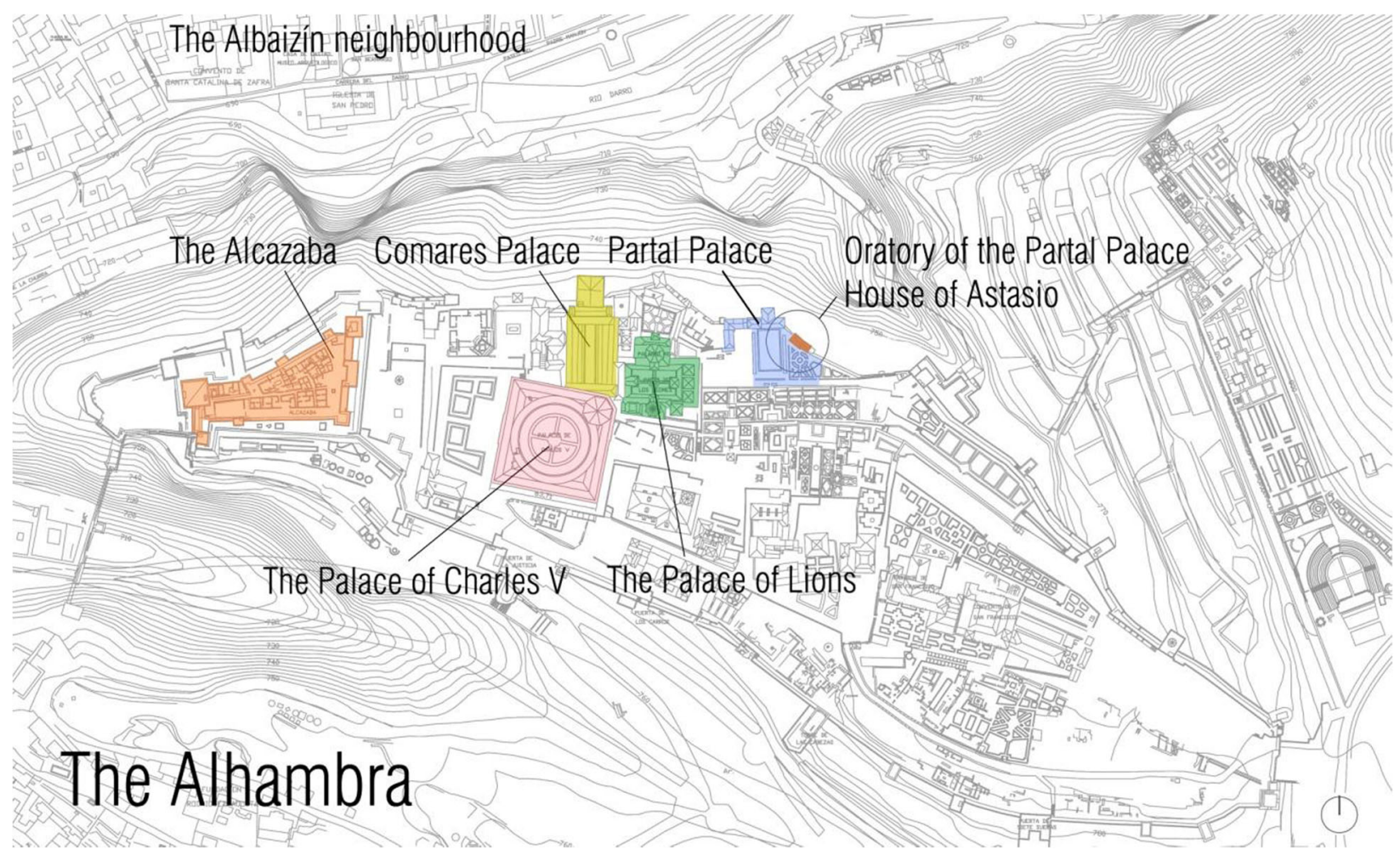

Fig. 2 The Partal Palace in relation to the other preserved royal palaces of the Alhambra: the Palace of Comares, the Palace of the Lions, the Palace of the Emperor Charles V, the Albayzín neighbourhood and the Alcazaba fortress (Source: the author)

independent space on a lower level is also accessible from the gardens. Both spaces were built earlier than the Oratory (Torres Balbás 1945).

As shown in a longitudinal section (Fig. 6, left), the entrance to the Oratory opens into a very narrow threshold space covered by an original wooden ceiling, which leads to the main inner space of the mosque through a semicircular, richly decorated arch. The mosque's mihrab, visible from the exterior through the entrance door and located on the other end of this main space, is covered by a muqqarnas vault. The central praying space is covered by the original Nasrid decorated timber frame, the main focus of the 2013-2017 restoration.

This decorated timber frame, initially built as an independent structure from the upper roof, exhibited substantial deformations due to its inadequate ability to bear the roof's load.

The House of Astasio has three levels, the upper being accessible by a staircase connected to its entrance from the Partal gardens (Fig. 6, right). This is a reduced space partially located over the referred Oratory's mihrab and therefore superimposed over it. It includes openings on its north-eastern side facing the Albayzín and towards the Partal gardens on its south-western elevation. The other two levels are the previously mentioned independent ground level and a lower space in the basement, accessible by another door.

\section{The decorated timber framework}

The richly decorated timber frame (armadura apeinazada) covering the central space of the mosque (Fig. 7) constitutes a unique heritage element and is one of the best-preserved examples of a decorated timber structure of the Nasrid dynasty, closely connected to the Christian-mudéjar ${ }^{2}$ medieval carpentry traditions but also distinctive from them in its construction techniques. It is formed by four slopes built of rafters and assembled noggings with interlaced patterns of eight-point stars at their lower and upper ends (Fig. 8). Each of these slopes was prefabricated at the carpentry workshop with their rafters attached to diagonal rafters running along its lateral sides (limas moamares). The previously mentioned assembled noggings also provide enough rigidity to make these slopes structurally cohesive and therefore manageable for transportation to the building site for final assembly.

Once on site, the upper ends of each slope's rafters were then inserted into their corresponding horizontal

\footnotetext{
${ }^{2}$ Mudéjar: A syncretic medieval architectural style that combines Christian and Muslim constructive, architectural and decorative traditions. Since the end of the twelfth century, this style was conceived and implemented for the construction of medieval Christian churches and palaces by craftsmen of Hispano-Muslim backgrounds who had settled in the Northern Christian Kingdoms of the Iberian Peninsula.
} 


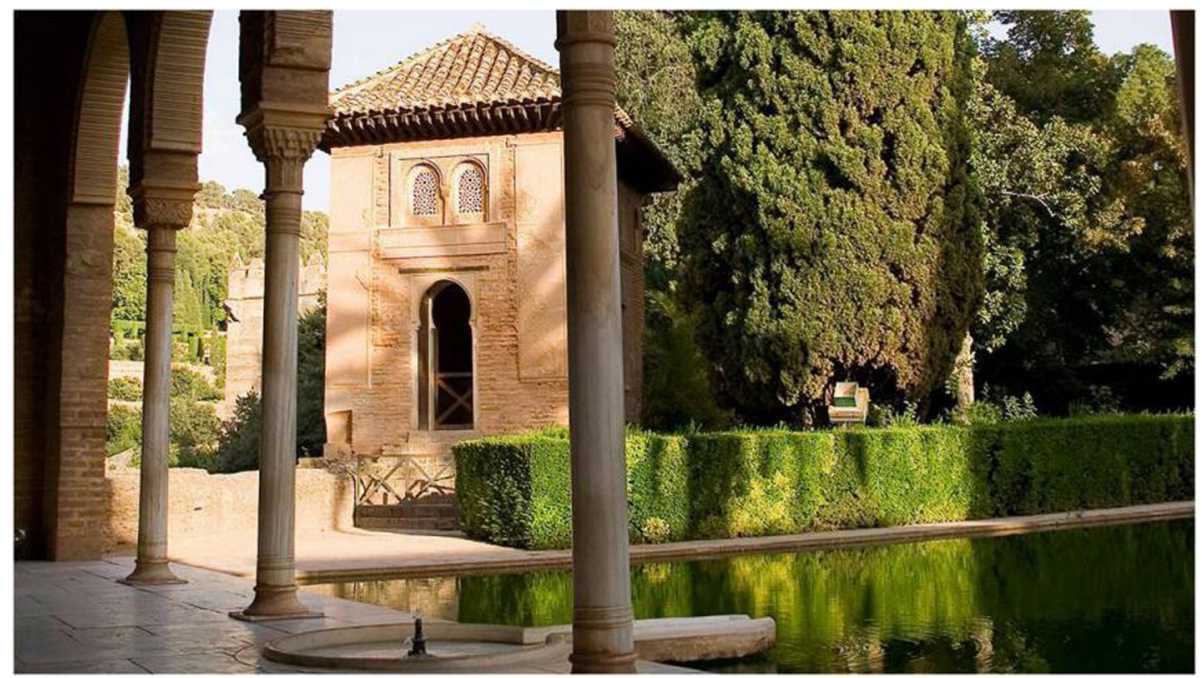

Fig. 3 The Oratory from the portico of the Partal Palace in 2017 (Source: the author)

collar ties, thus forming the horizontal plane, called the almizate, at the top of this structure, as shown at the centre of Figs. 7 and 8.

The almizate (Fig. 8 centre), formed by successive collar ties that were also prefabricated at the carpenter's workshop, displays a complex decorative pattern formed by its parallel collar ties assembled with structural noggings and additional decorative elements. This avant-lalettre prefabricated building process enabled its very careful fabrication at the carpenters' workshop, hence the very sophisticated level of construction reached.

The different kinds of timber used in the structure were those most commonly used in the Nasrid context during the 14th century. The almizate and the common rafters are made of silver poplar (Populus alba L.), while the central rafters in the north-eastern and southwestern slopes are made of Aleppo pine (Pinus halepensis Mill.) (Rodríguez Trobajo 2014, 1). The reduced dimensions of this structure enabled the use of silver poplar, a widely available although weaker wood, for most of its elements, while the central rafters of these two slopes are made with the more resistant Aleppo pine, as these elements bear a greater structural load (Fig. 8, lighter blue central rafters).

As shown in the longitudinal section in Fig. 6 and in the following detailed cross section in Fig. 9, the

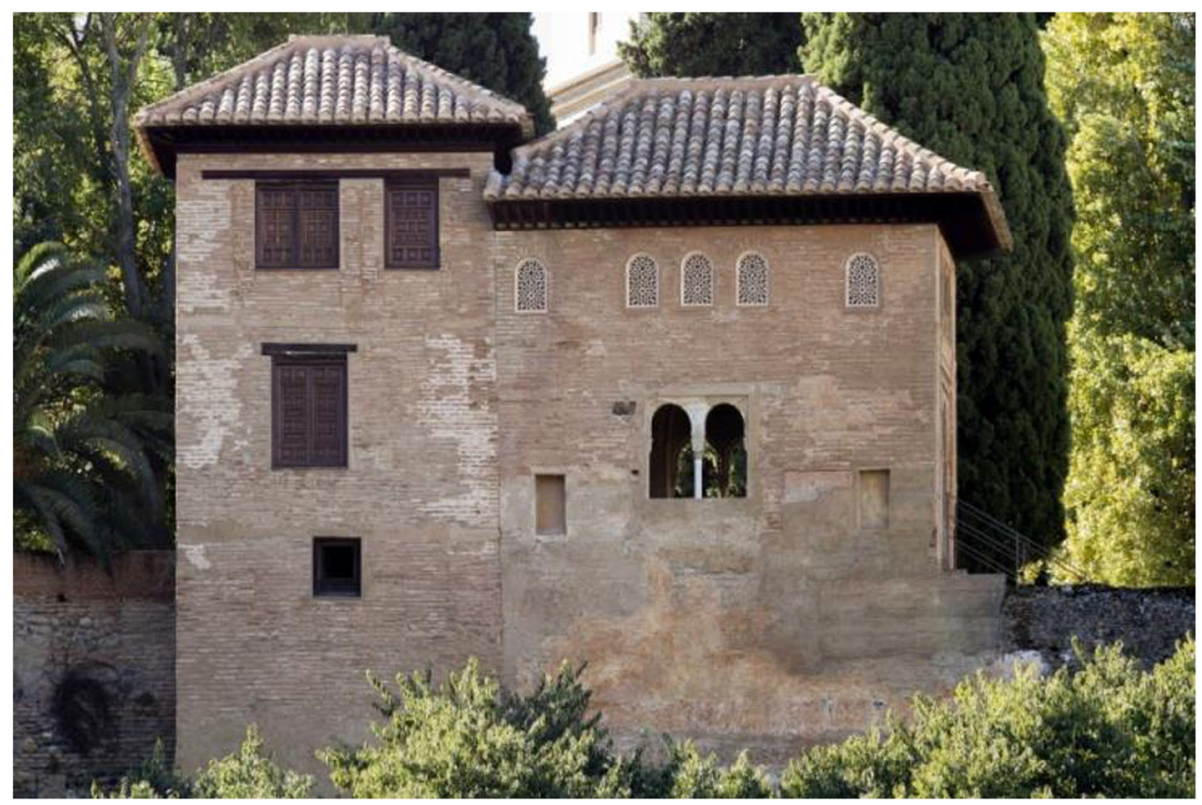

Fig. 4 North-eastern elevation of the Oratory and the House of Astasio, both built over earlier defensive walls (Source: Artyco 2015) 


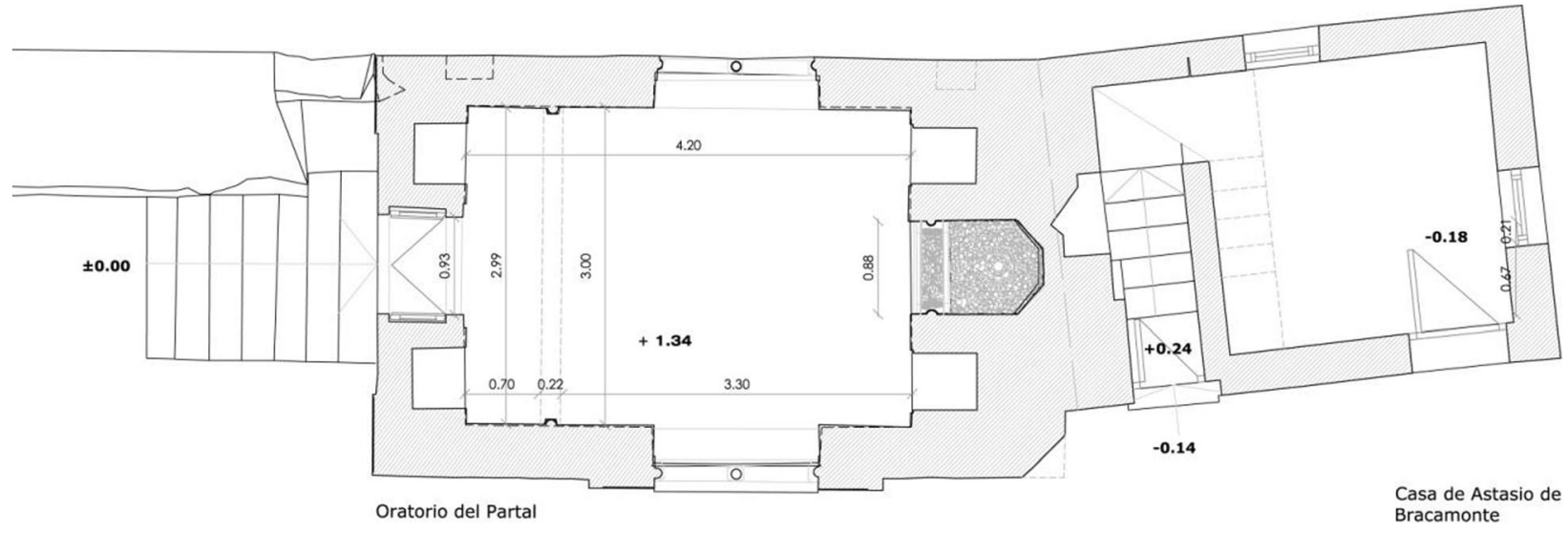

Fig. 5 Plan layout of the Oratory (left) and the House of Astasio de Bracamonte (right) (Source: Wulff Barreiro 2012)

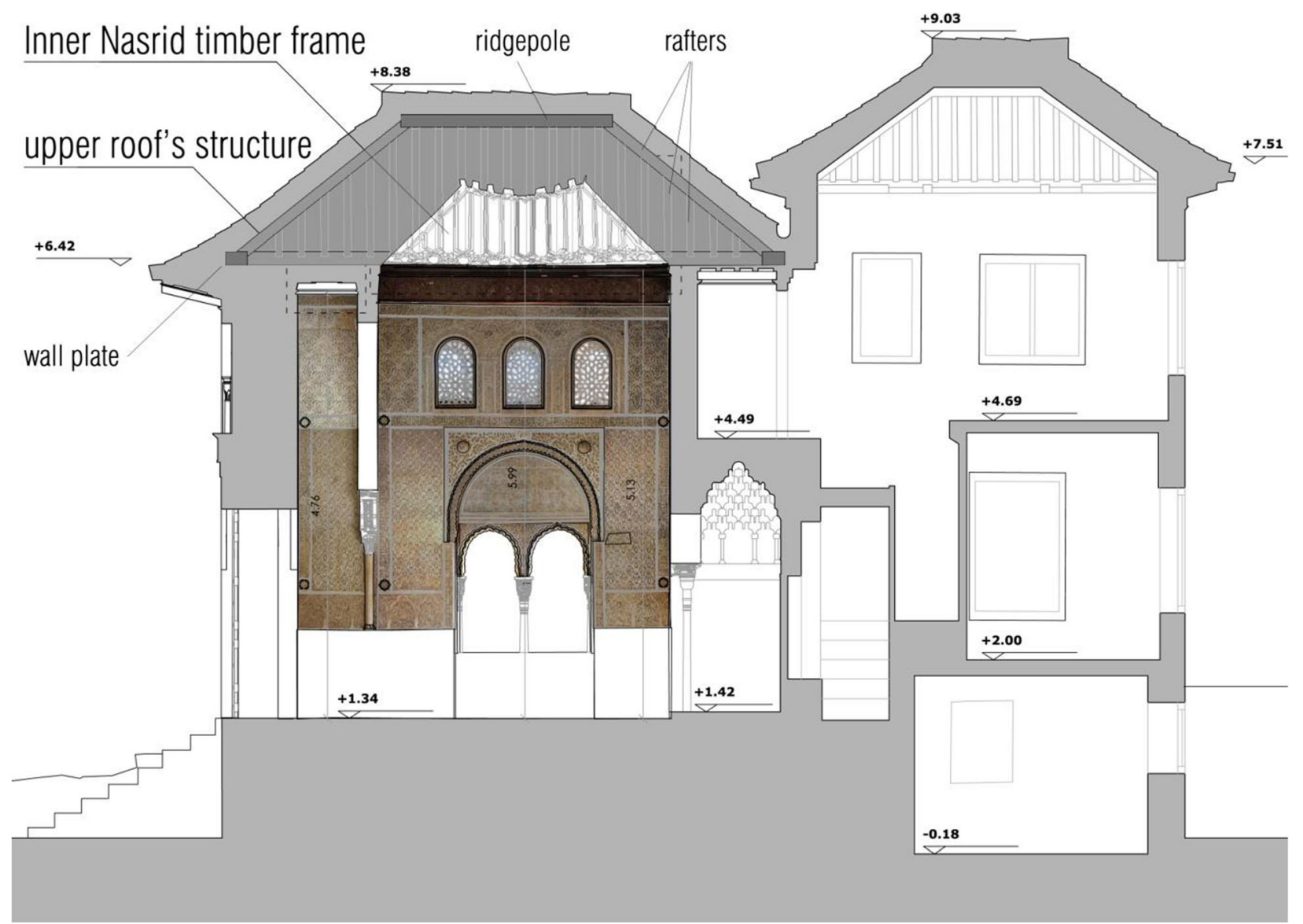

Fig. 6 Longitudinal section of the Oratory and the House of Astasio, illustrating the independence of the Oratory's upper roof structure from the inner decorated timber frame dated to the Nasrid period. Additionally, note the delicate encounter between the Oratory and the House of Astasio's roof slopes, which had caused a major rainwater penetration issue (Source: Wulff Barreiro 2012) 


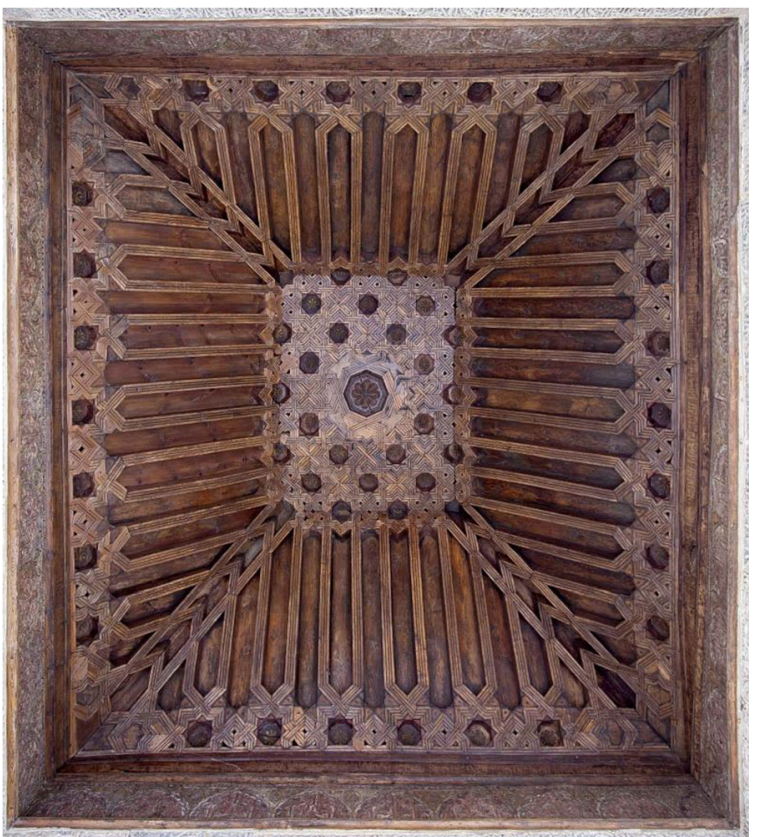

Fig. 7 Decorated timber framework after the 2013-2017 restoration (Source: Artyco 2015)

original decorated timber frame was initially totally independent from the roof upper structure, thus exclusively bearing its own load. As becomes apparent in the subsequent analysis of the timber frame's condition prior to the 2013-2017 restoration, the structural failure of the upper roof's rafters led to their inadequate bearing upon the delicate inner timber frame, causing a major warping of its almizate (Fig. 12).

This structural typology, characterised by its truncated pyramid shape and the assembled interlaced decorative-but also structural-noggings, was present in other buildings from the same period in the $\mathrm{Al}$ hambra and in the medieval city of Granada. They were built during a very specific period between the last decades of the 13th century and the mid-14th century (Wulff Barreiro 2011). Afterwards, the high level of geometrical and technical skills required for the carpenters to undertake their construction led to their substitution with simpler and non-structural decorative ceilings that were directly nailed onto hidden rough roof structures. However, in the Christianmudéjar context, the same structural typology-although using slightly different techniques and proportions-survived until the 18th century in Spain and Latin America. In the Alhambra, this typology covers the Royal Hall (Sala Regia) of the Generalife Palace (the summer residence of the sultan), the Tower of Machuca and the "Painting House" (Casa de las Pinturas), also located in the Partal Palace complex. In the city of Granada, the Royal Hall of St. Dominic (Cuarto Real de Santo Domingo), a Nasrid palace built under the second Nasrid sultan Muhammad II (1273-1302) and therefore before the Partal Palace, is

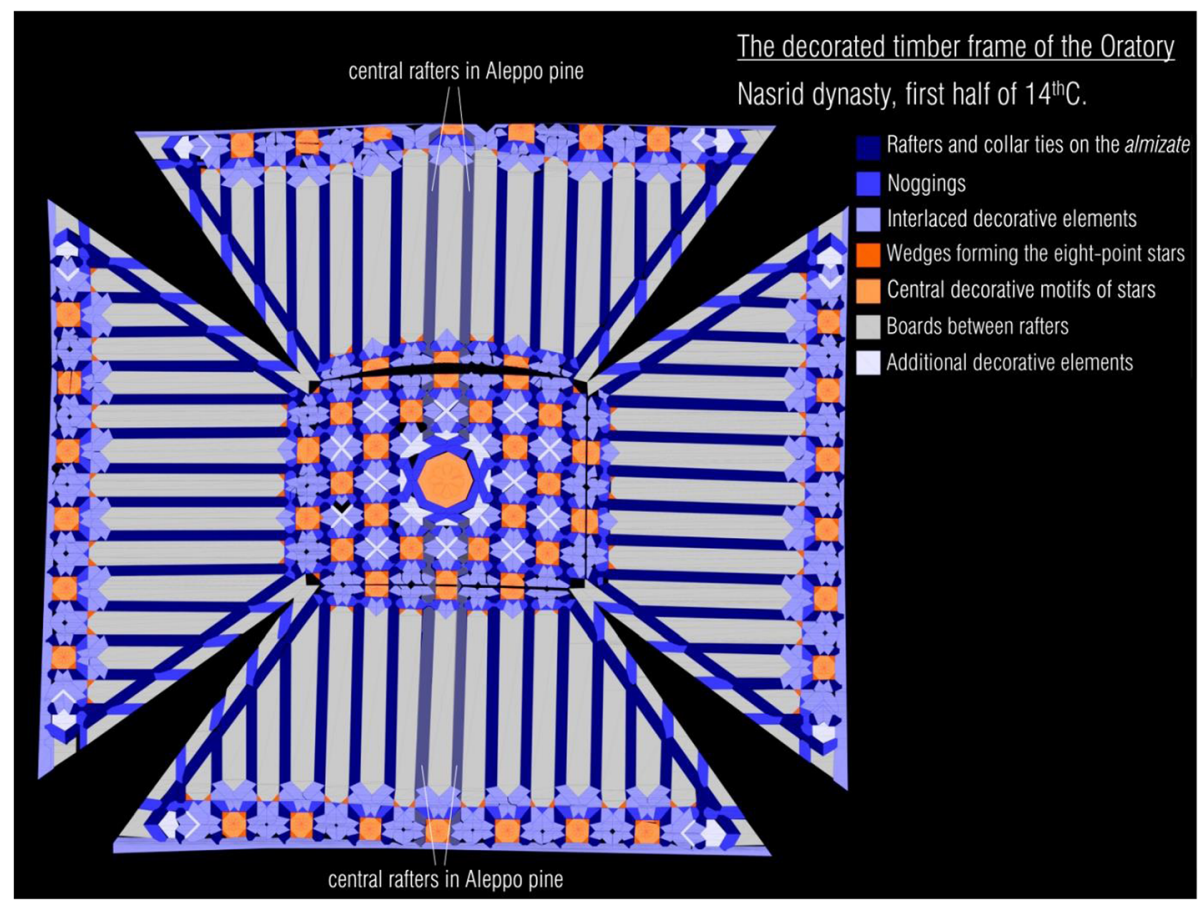

Fig. 8 Decorated timber framework. Carpentry elements: Rafters, noggings, interlaced decorative elements, and eight-point stars. Note the Aleppo pine central rafters on NE and SW slopes (Source: Wulff Barreiro 2012) 


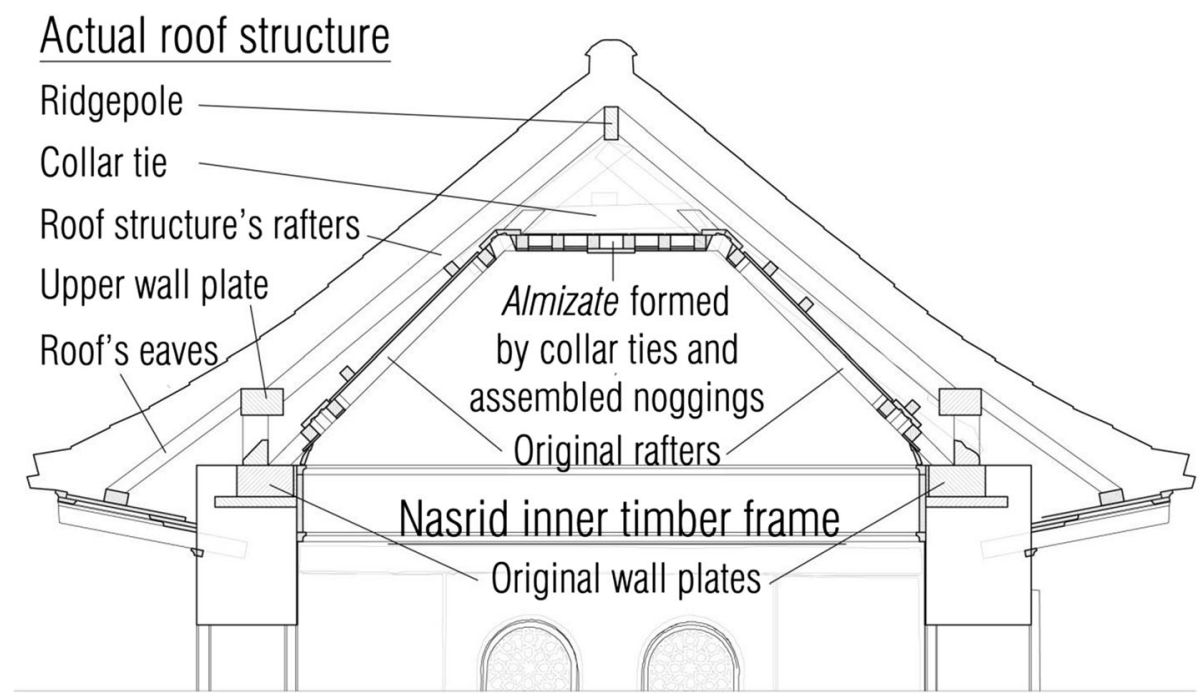

Fig. 9 Detailed cross-section of the Oratory's actual roof structure and inner decorated timber frame after the 2013-2017 restoration, illustrating the independence of their structures (Source: Artyco 2015; adapted by the author)

also covered by this typology. This is the largest and oldest preserved structure of this typology in the Nasrid sultanate of Granada, with a consistent dendrochronology dating of 1281 (Almagro Gorbea and Orihuela Uzal 1995, 1997; Rodríguez Trobajo 2008: 33-53).

\section{6 and 1930 historical restorations}

In 1846, the private owner of both buildings, Mr. Acebal, commissioned Rafael Contreras to conduct a restoration that would be aligned with the European Orientalist and eclectic trends of their time, close to the ideas of the French architect Viollet-le-Duc on recovering the

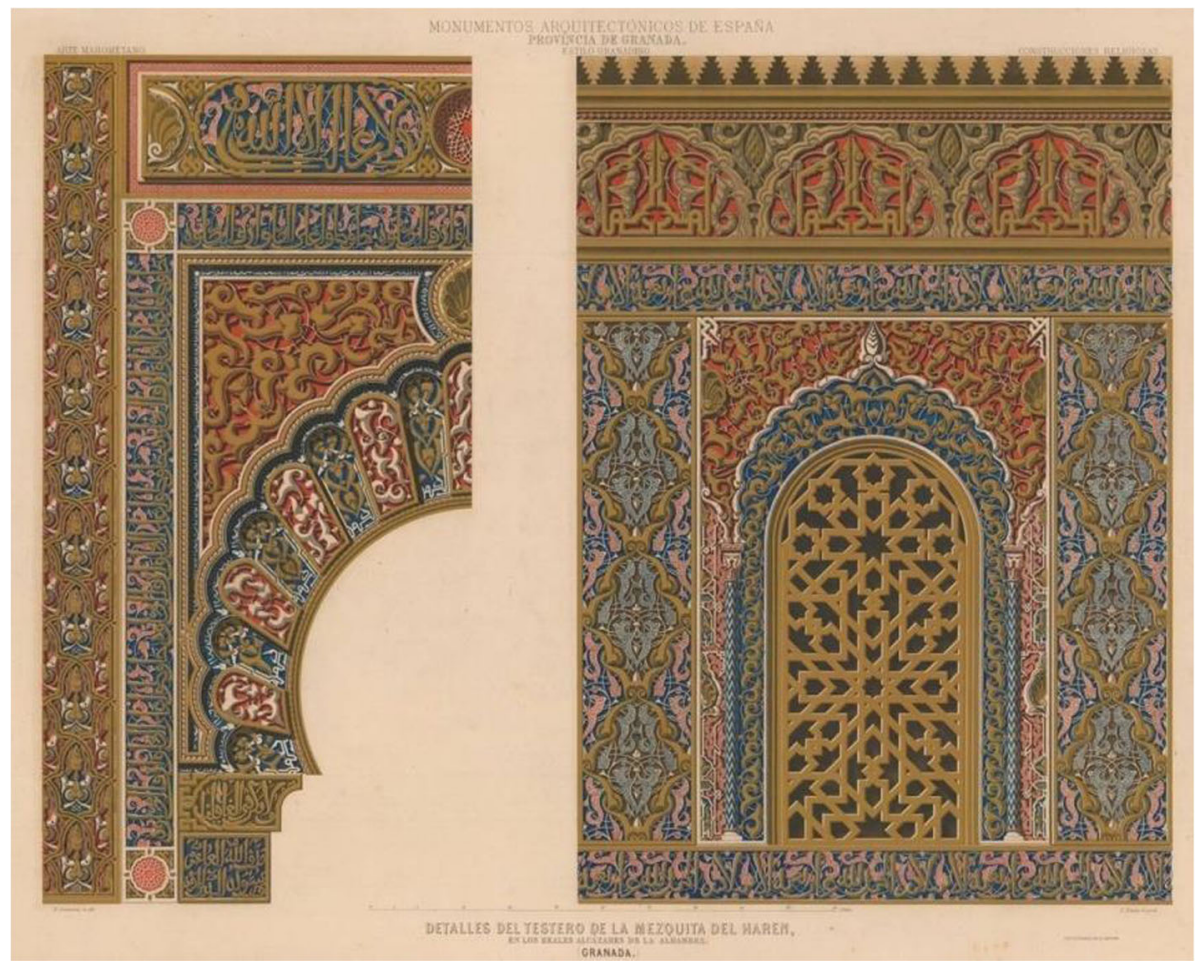

Fig. 10 Rafael Contreras' restoration plans from 1846, detail of the mihrab (Source: APAG, Historical Archive of the Council of the Alhambra) 
original 'atmosphere' of restored buildings by making 'creative' reinterpretations of the missing parts (Torres Balbás 1945, 114). However, based on his extensive knowledge of the Nasrid ornamental grammar of the Alhambra, Rafael Contreras was able to be very rigorousfor his time-in his restoration (Fig. 10). His sensitive and detailed intervention was deeply influenced by Owen Jones' decorative studies of the Alhambra, which had been undertaken and published some years earlier (Jones and de Gayangos 1842, Jones and Goury 1845; Contreras 1878).

The last major restoration of the Oratory was undertaken in 1930 by Leopoldo Torres Balbás, the Director of the Alhambra from 1923 until 1936, the final year of the Spanish Second Republic (1931-1936) (Torres Balbás 1945, 1969). Torres Balbás has been considered the

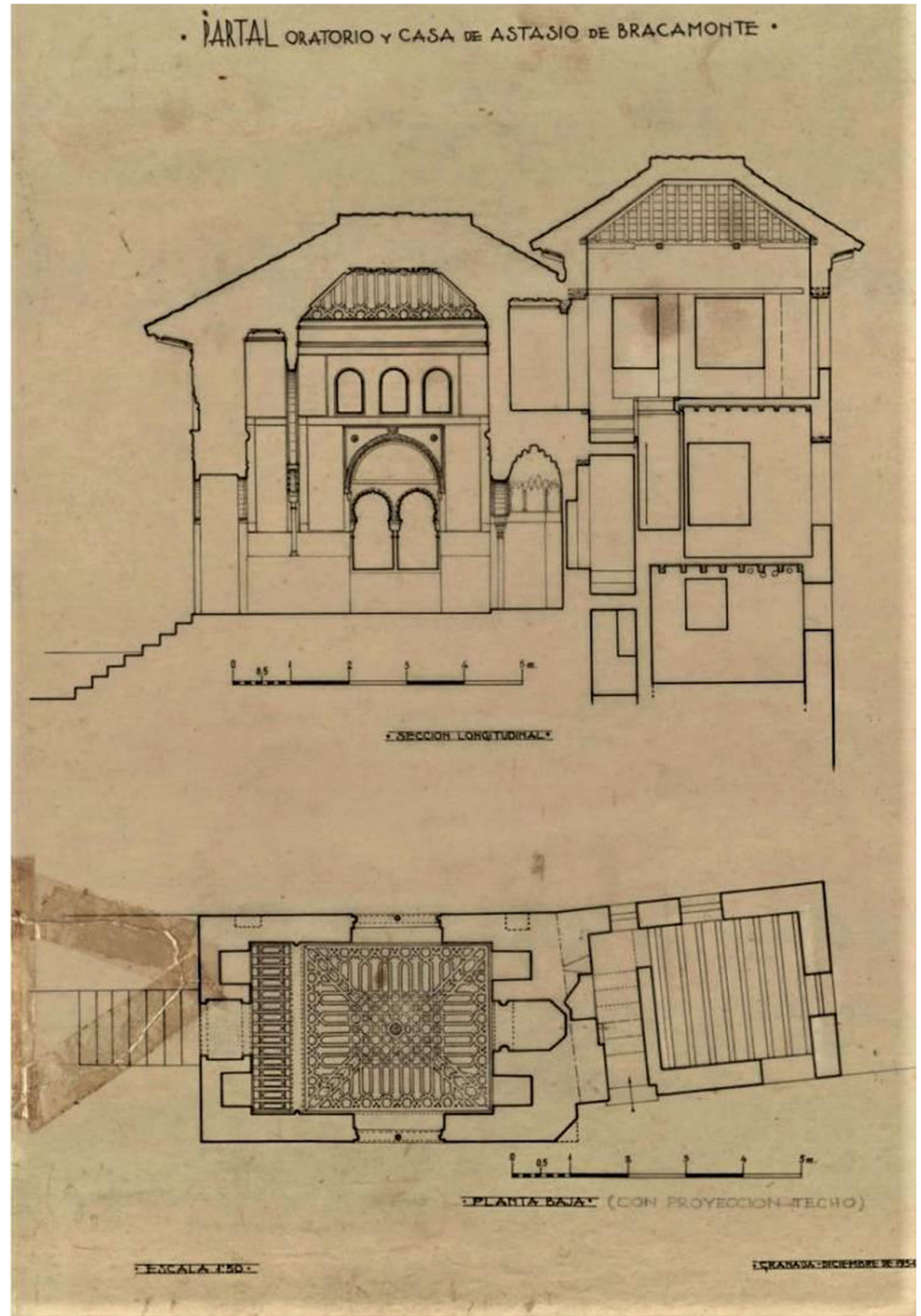

Fig. 111930 restoration by Leopoldo Torres Balbás. Longitudinal section and ground floor plan (Source: APAG, Historical Archive of the Council of the Alhambra) 


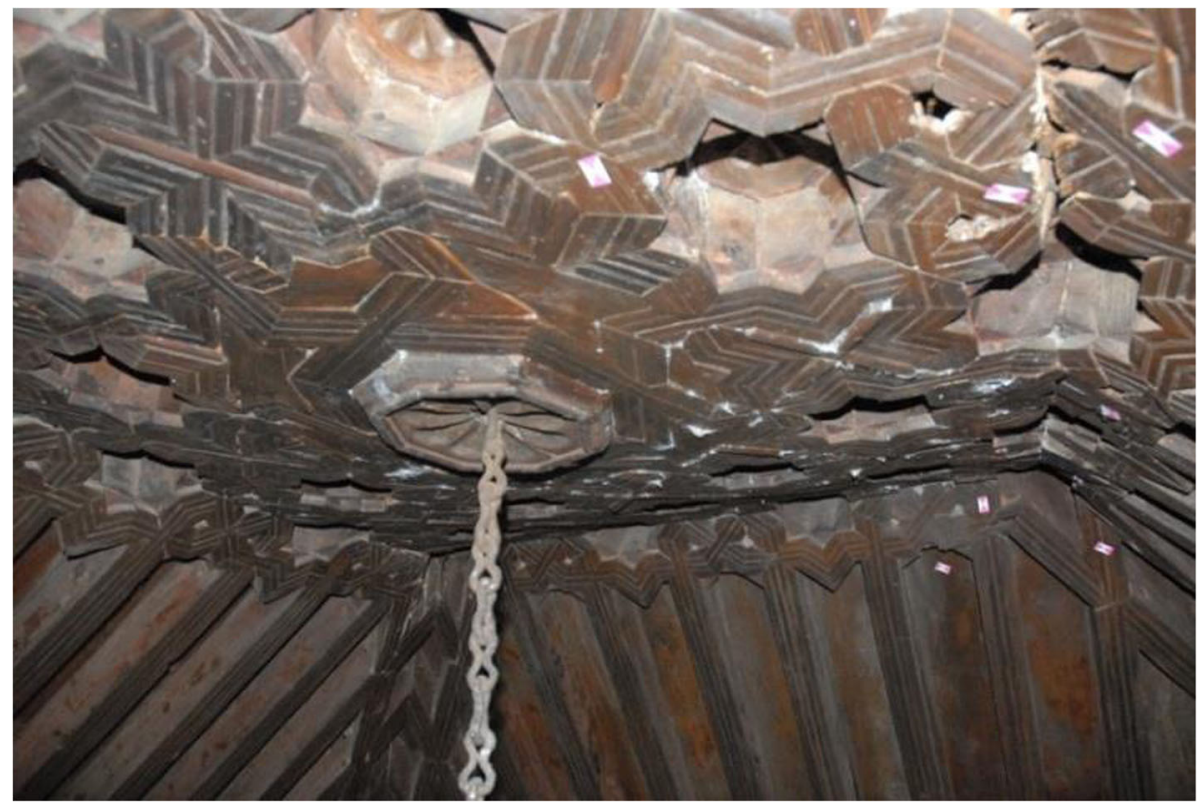

Fig. 12 Profound warping in the upper horizontal plane of the decorated timber framework, the almizate (Source: the author)

initiator of and the most important reference for modern architectural restoration in Spain, in close relation to the most prestigious European heritage architects and architectural historians of his time, such as Gustavo Giovanonni in Italy and Henri Terrasse in France (Rivera Blanco 2013). With a rationalist mindset, Torres Balbás' initial approach was the selective removal of all added elements from previous historical restorations, such as the aforementioned 1846 Rafael Contreras intervention. The goal was to enable the exclusive legibility of the 'authentic' medieval Nasrid remains without giving any concessions to subsequent interpretations (Fig. 11). However, for the first time ever in a Torres Balbás restoration, in the Oratory, he acknowledged Rafael Contreras' profound understanding of Nasrid ornamental language. Torres Balbás decided to retain the best parts of Contreras' intervention, considering them highquality interpretations of the missing parts. His restoration approach evolved from an initially radical rationalist standpoint, typical of the 20s-30s in the twentieth century, to more advanced eclectic criteria, as he himself defined his restoration (Torres Balbás 1945).

\section{The Oratory of the Partal Palace as a compendium of the last 180 years of Spanish heritage preservation approaches}

The relevance of both the 1846 and the 1930 restoration lies in both being high-quality cultural expressions of their respective European historical contexts. The former was an interesting example of the romantic, orientalist and eclectic trends of the mid-19th century that was also rigorous in its knowledge of Nasrid architecture. The latter illustrates a very advanced approach that went beyond the European rationalist trends of the time. The mere search for a controversial Nasrid 'authenticity' was overtaken by a complex approach based on an appreciation of the qualities of the previous Rafael Contreras intervention. These ad hoc design and preservation decisions might be closer to contemporary approaches to European heritage preservation.

These two historical restorations and their associated heritage values, together with other subsequent minor repairs (Prieto Moreno 1968), enable the interpretation of the Oratory of the Partal Palace as an architectural compendium of the last 180 years of heritage preservation approaches in Spain, from the 1846 Orientalist restoration through the 1930 scientific-eclectic restoration, to the 2013-2017 intervention, based on preservation and legibility.

\section{5 and 2007 preliminary reports}

The Council of the Alhambra and Generalife commissioned the practice Wulff-Guirnaldos Architects to compile two preliminary research reports focusing on the analysis of the 19th and 20th century historical restorations (Wulff Barreiro 2005) and on the constructive condition of both buildings (Wulff Barreiro 2007). The first report (2005) focused on archival research, conducted in Granada $^{3}$ and Madrid ${ }^{4}$, on the preserved graphic and written documents related to both buildings and their historical restorations. The second report (2007)

\footnotetext{
${ }^{3}$ The Historical Archive of the Council of the Alhambra.

${ }^{4}$ The General Archive of the Central Public Administration of Spain.
} 
included a thorough constructive analysis using photogrammetric and laser techniques. The outcomes of these reports were twofold: on the one hand, the successive heritage values added to the building by the historical interventions and the importance of their preservation and legibility were acknowledged; on the other hand, increasing the awareness of the need for an urgent restoration of the original timber framework, the condition of which was concerning.

\section{Condition of the two buildings before the 2013 2017 restoration}

\subsection{Hipped roofs}

The 1930 restoration included an inadequate redesign of the roofs covering the two buildings that was meant to enhance their distinctive legibility (see Figs. 4 and 6). The Oratory was covered with a hipped roof that has since poured rainwater off its southeastern side against the north-western wall of the House of Astasio, which is slightly higher. Similarly, the House of Astasio was covered by another hipped roof, the north-western slope of which drained rainfall into the same encounter, a problem which was solved with a valley gutter. While the rest of the 1930 intervention could be considered excellent, the design of this encounter was probably its worst design decision from a construction perspective. Since then, it has caused dampness issues on the north-western brick wall of the House of Astasio. The lack of a good waterproofing solution for the valley gutter has resulted in rainwater penetration into the inner spaces. This has produced moisture and led to the decay of parts of the decorated timber framework, together with the degradation of the timber structure and the ceiling covering the overlapping space between the Oratory and the House above the delicate mihrab.

\subsection{Structural and constructive pathologies}

As discussed in the 2007 preliminary report, the pathologies prior to the 2013-2017 restoration were divided into two main categories:

A. Structural issues in both the roof of the Oratory and its inner decorated timber framework

B. Local constructive pathologies caused by structural movements, dampness and organic remains.

Regarding the structural pathologies, the upper horizontal plane (almizate) of the inner decorated timber framework was profoundly warped due to the inadequate load-bearing of the upper roof, which demanded an urgent structural intervention (Fig. 12).

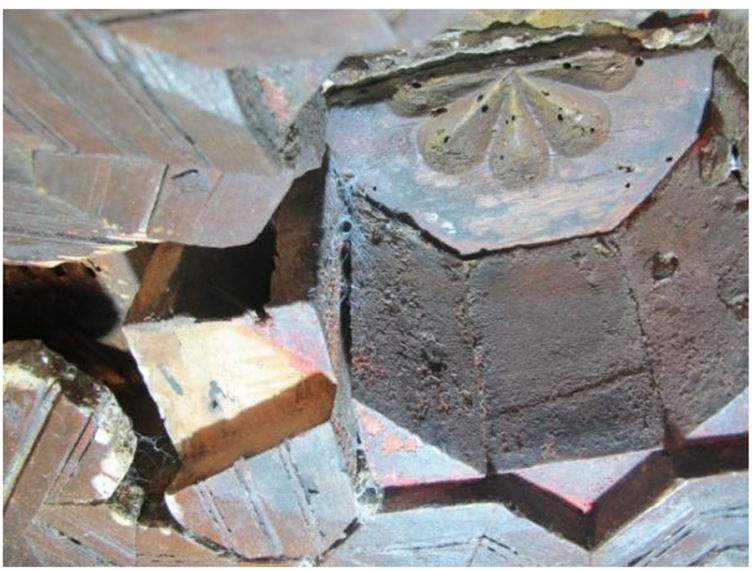

Fig. 13 Disassembled eight-point star on the encounter between the almizate and one slope (Source: Artyco 2015)

In addition, the inner north-eastern slope of this framework was severely deformed due to the descent of its central rafters, produced by their failure to provide support at the wall-plate level. This was due to the moisture degradation of the rafters' lower ends and its timber wall plate, both caused by rainwater penetration.

The disintegration and loss of original elements in several carpentry nodes of the decorated timber framework was a consequence of the aforementioned structural movements and rainwater penetration. The detail shown in Fig. 13 of a disassembled decorative

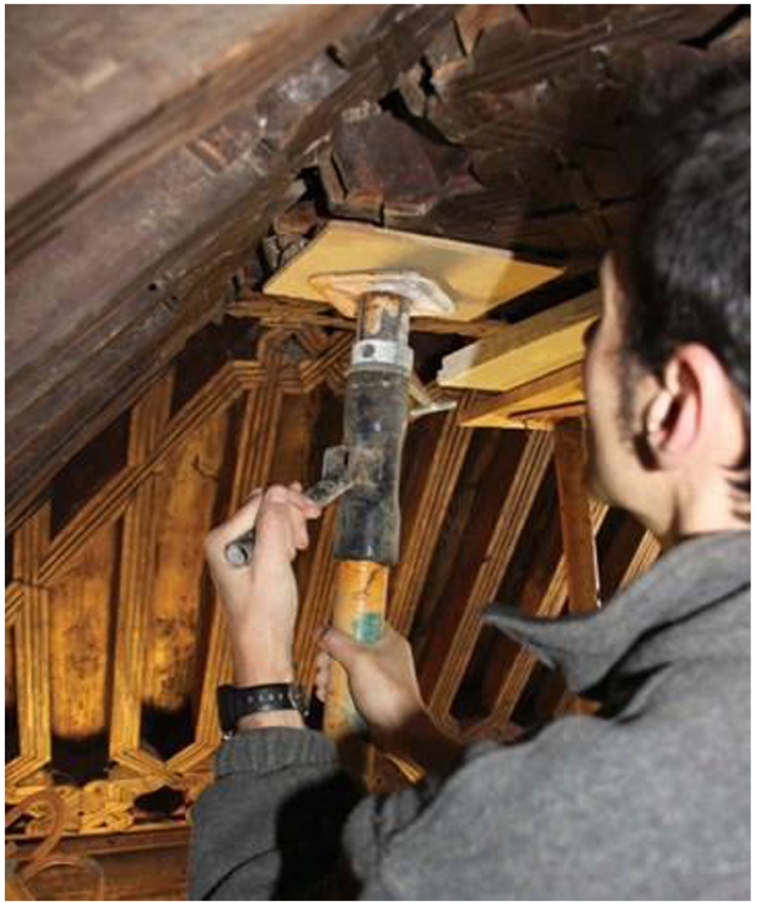

Fig. 14 Recovery of the structural deformations in the decorated timber framework using a mechanical jack (Source: Artyco 2015) 


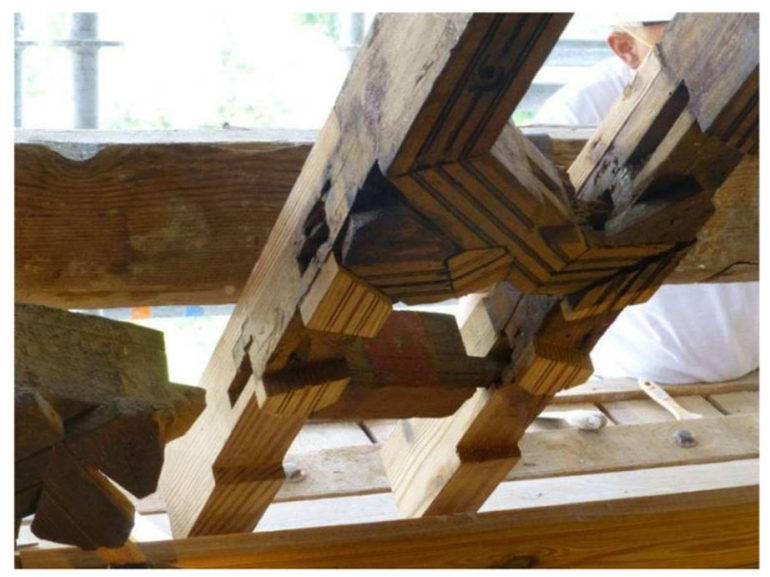

Fig. 15 Lower end of the rafters on the N-E slope, including the reintegration of the missing parts with new assembled insertions. This node illustrates the sophisticated and distinctive techniques of Nasrid carpentry compared to Christian-mudéjar carpentry (Source: Artyco 2015)

eight-point star motif on the encounter between the horizontal plane (almizate) and one of its slopes demonstrates its disintegration, the loss of its original decorative elements and attacks by wood-eating insects (xylophagous). Generalised surface dirt caused by the accumulation of layers of dust and insect nests were also apparent. Finally, the peeling and degradation of the original painted decorations was also a serious issue to address (Artyco 2015). During the 1930 restoration, several layers of linseed oil were applied over the timber framework, causing to become generally darkened, dirty and oxidized (Artyco 2015, I, 487). As a consequence, its original paint lost its mechanical resistance and gradually peeled. During the 2013-2015 restoration, these timber elements were cleaned, and their paint was consolidated and restored.

\section{Restoration phases}

Based on the 2005 and 2007 preliminary reports, the Council of the Alhambra decided in 2010 to undertake a restoration that would be articulated into three phases:

\subsection{Phase 1 (2013-2015)}

This phase consisted of dismantling the roof that had been built during the 1930 restoration to access the external side of the inner timber framework. Several original timber elements forming part of the Nasrid upper roof structure were then discovered within the confined space within the upper roof structure and the inner timber framework (Fig. 16). These elements were consistently dated as belonging to the original Nasrid building (Uppsala Universitet 2014). The upper roof structure from the previous 1930 restoration was entirely recovered by reusing its carpentry elements, as they were extremely well preserved. Special attention was given to the valley gutter area that collected rainwater from the Oratory and the House of Astasio slopes, which had caused the major rainwater penetration issues (see Figs. 4, Fig. 6 and Section 7.1. Hipped Roofs). This area was reinforced with a waterproof permeable membrane to allow the timber structure to breathe, a lime mortar coating and a 3 $\mathrm{mm}$. lead sheet for the external formation of the new valley gutter (Artyco 2015, II: 158-162).

\subsection{Phase 2 (2013-2015)}

Simultaneously to Phase 1 , the analysis and restoration of the original inner timber framework and the ceiling of the entrance space were performed in Phase 2. The good condition of most of its original timber elements enabled their structural deformations to be addressed by recovering their original shape and by reassembling their nodes without any other additional reinforcements. The almizate was straightened up,

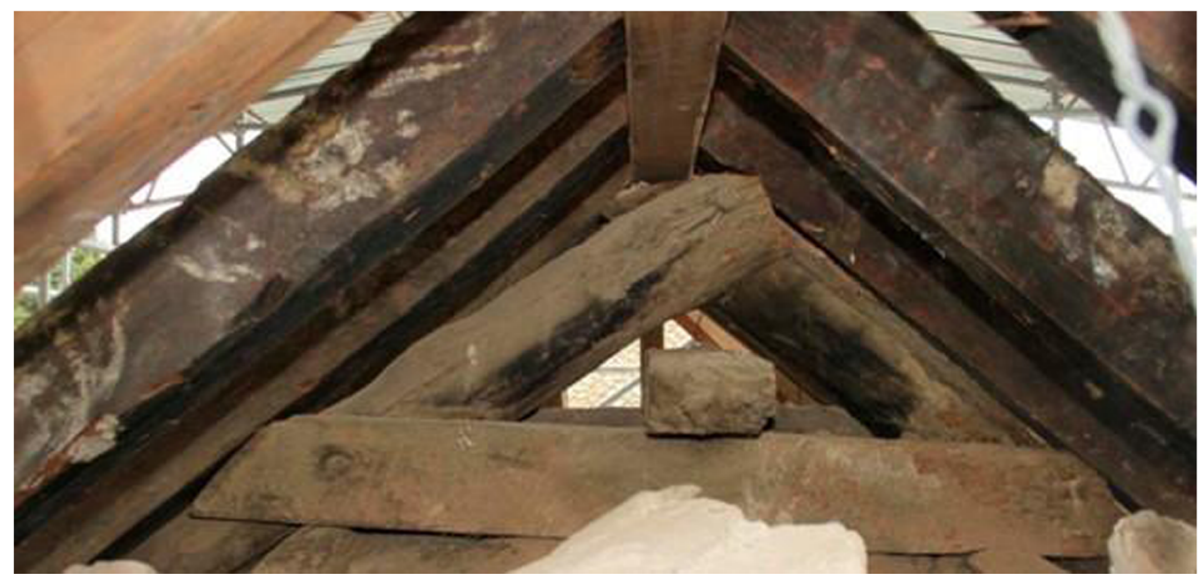

Fig. 16 Some rafters and a double false collar tie from the original Nasrid roof structure preserved beneath the upper roof structure built by Leopoldo Torres Balbás during his 1930 restoration (Source: Artyco 2015) 
and its separation from the slopes was corrected using mechanical jacks (Fig. 14).

New structural insertions and decorative elements were added where needed in the missing areas and were distinguished from the originals and from previous historical restorations by their different finishing.

As analysed in the Conclusions section, decorative vegetal and epigraphic motifs dated from the 14th century Nasrid period that were unknown to date were discovered, consolidated, restored and interpreted within their wider historical contexts. The restoration of all decorative painted motifs has improved their legibility, enabling distinctions to be made between the originals and the historical restoration repaints (Artyco 2015, I: 455-457).

\subsection{Phase 3 (2015-2017)}

The focus in this phase was on the restoration of the decorative and epigraphic motifs applied to the plasterwork covering the inner walls and the mosque's mihrab. Additionally, the external brick walls were cleaned and consolidated using ethyl silicate. The intervention to reinforce the brick wall fabric was performed with lime mortar stripes on its accessible edges. Additionally, PLM-A ${ }^{\circ}$ hydraulic mortar was injected at strategic points that exhibited a potential risk of fabric detachment (Artyco 2015, II: 185).
The aforementioned initial rationalist search for 'authenticity' by Torres Balbás resulted in an excessively abrasive cleaning process of all the plasterwork repaints, thus making the Nasrid decorations indistinguishable from the 19th century restorations; in many areas, it unfortunately removed both. During the 2013-2017 restoration, a thorough study focusing on the different painting techniques of the two periods and a chemical analysis of their colouring pigments enabled those commonly employed during the Nasrid period to be distinguished from those discovered and employed since the 19th century (Parra Crego 2014). The criteria used for the painting restoration were based on the enhancement of the legibility of the original painted motifs and of the historical restorations without any giving any concession to creative interpretations or global modifications. This differentiation was done while keeping an overall coherence and homogeneity by using materials and techniques slightly differentiated from the previous historical layers, thus avoiding mimicry and the risk of creating false historicisms. Finally, the interventions were based on material reversibility, avoiding any aggressive interventions over the original paintings (Artyco 2015, II: 179).

\section{Conclusions. Innovative research outcomes from the 2013-2017 restoration}

The last restoration of the Oratory and the House of Astasio from 2013 to 2017 has provided important research contributions to a deeper understanding of

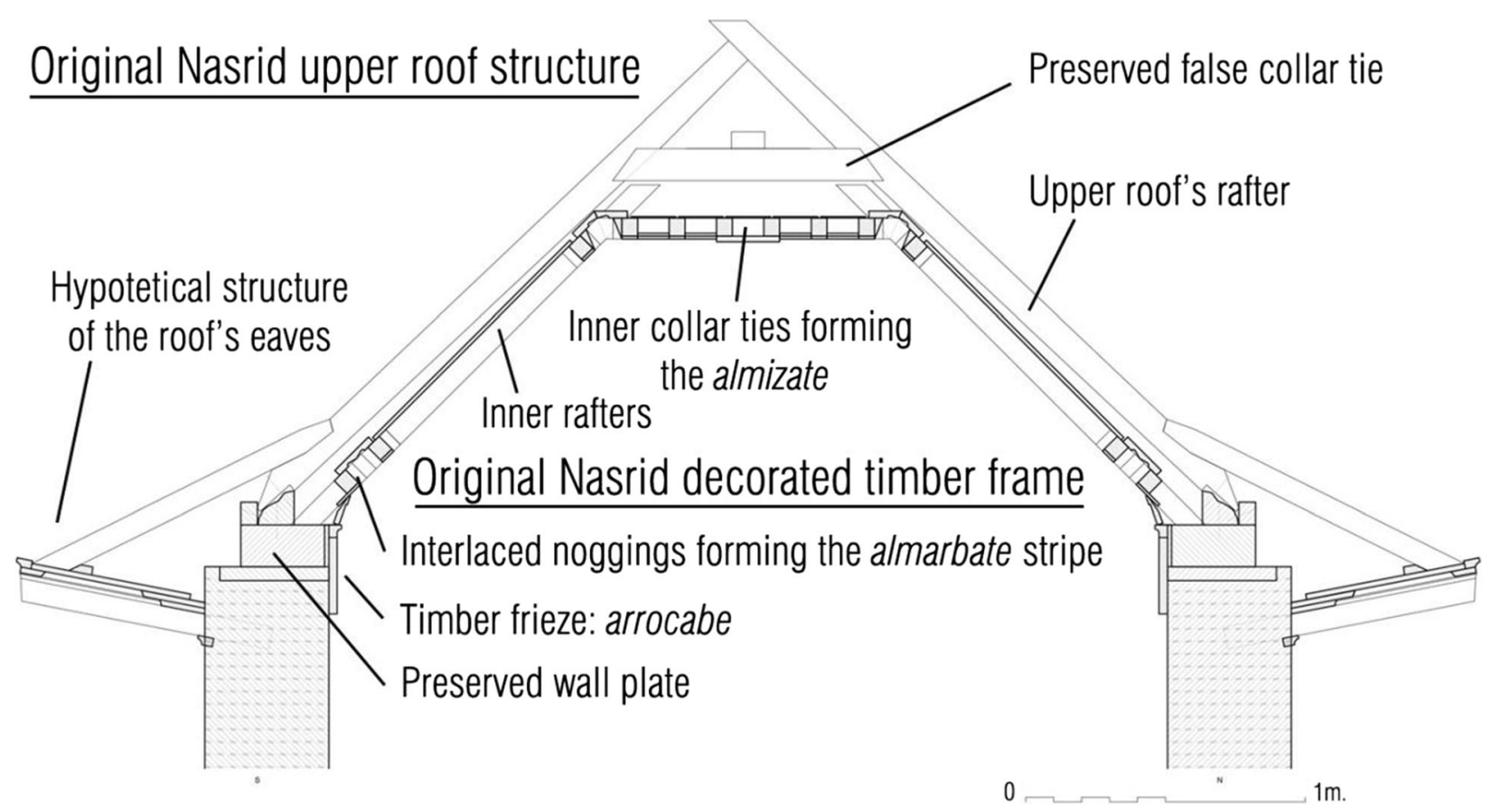

Fig. 17 Restitution of the original Nasrid upper roof structure based on the interpretation of its original elements, together with the original preserved inner timber frame. It includes a description of their carpentry elements (Source: Artyco 2015; adapted by the author) 


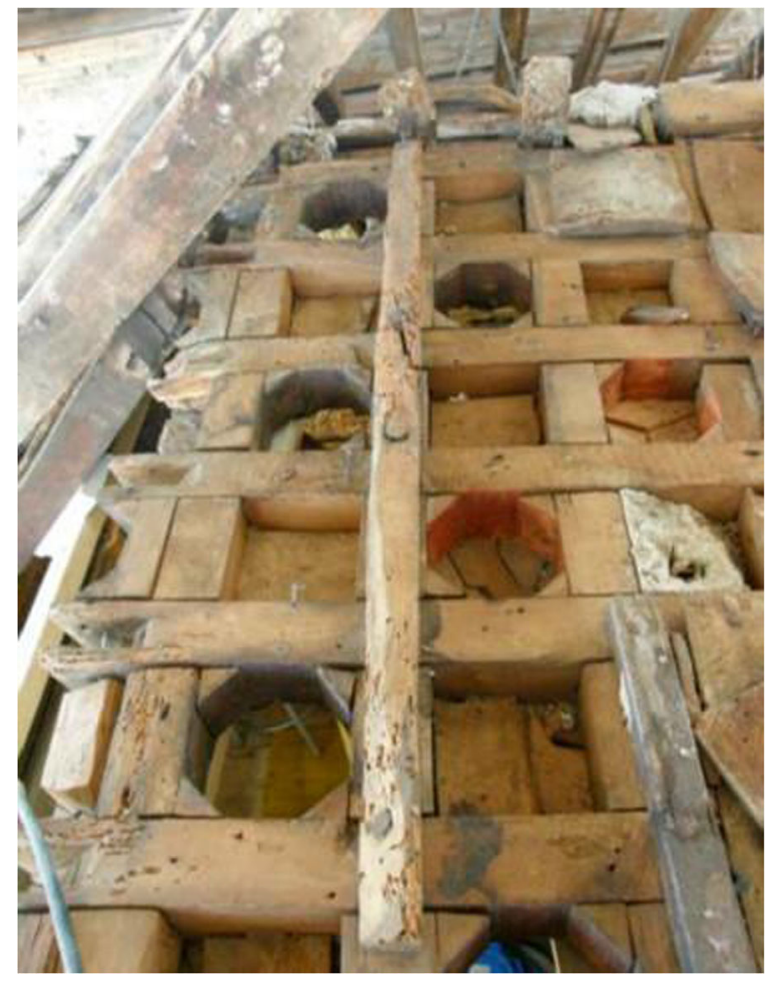

Fig. 18 External side of the almizate. Regular pattern of alternate octagons supporting the eight-point stars (Source: Rodríguez Trobajo 2014)

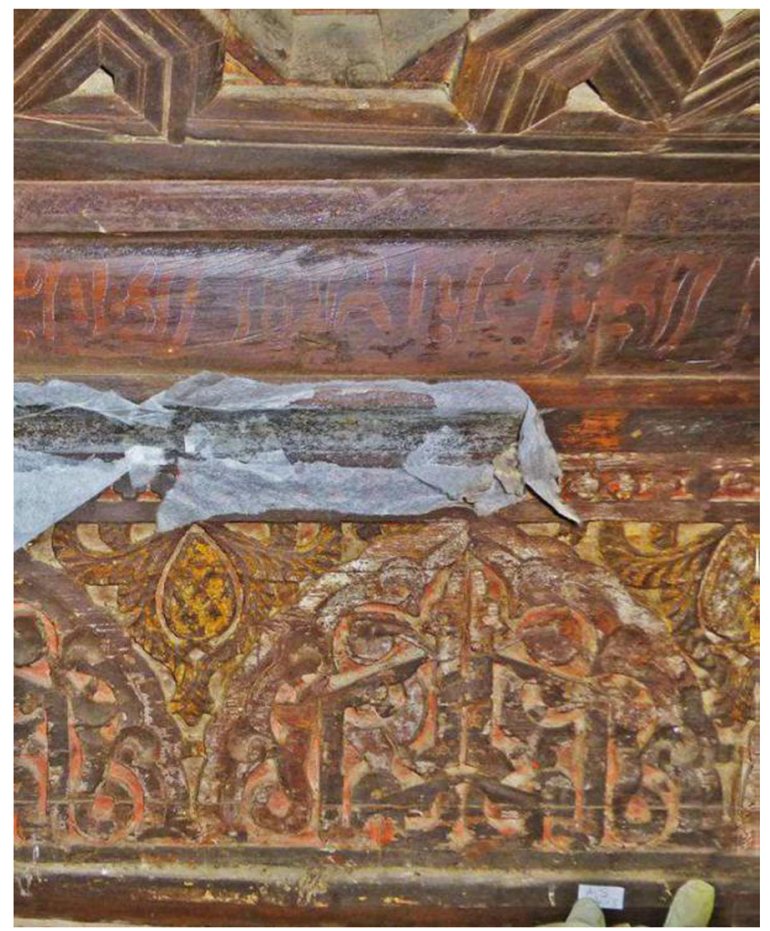

Fig. 19 Unknown epigraphic inscription recovered from the upper board of the timber frieze (Source: Artyco 2015)
Nasrid architecture, its constructive traditions, decorative programme and painting techniques. In addition, it contributed to expanding knowledge of Nasrid carpentry techniques, which were deeply influenced by but also clearly distinct from their contemporary Christian-mudéjar counterparts. Furthermore, the dendrochronology and carbon-14 tests have enabled entirely new dating for these two buildings, shedding light on their construction processes within the wider context of the Partal Palace complex (Uppsala Universitet, the Angström Laboratory / Tamdem Laboratory 2014; Rodríguez Trobajo 2014).

The reconstruction of the central rafters' support of the north-eastern slope, which was seriously degraded by rainfall, moisture and the action of xylophagous insects, enabled a detailed constructive analysis of their original geometries and assembly systems. This has provided further evidence of the quality levels reached by Nasrid carpenters as distinctive from their Christian-mudéjar contemporaries. As shown in Fig. 15, the severe degradation of the rafters and their assembled noggings on the lower end of this slope guided the reintegration of their missing parts with newly assembled timber elements made of yellow pine (Pinus taeda) and glued to the original rafters with epoxy resin. These rafters' lower ends were originally carved out with mortises on both sides for being assembled to the noggings, forming the upper and lower frames of the decorative eight-point star motifs (Fig. 15).

These motifs, working as stiffeners for the structure, were slotted within each pair of rafters, forming a continuous decorative and structural stripe at the lower level of the timber framework (almarbate stripe). Finally, additional decorative motifs (taujeles) were nailed to the rafters' lower sides to complete the eight-point star motifs.

In Phase 1, the dismantling of the upper roof structure that was built during the 1930 restoration, revealed unexpected findings. Fragments of the original Nasrid upper roof structure that had been unknown to date were discovered within the confined space between the Nasrid inner decorated timber framework and the new external roof structure.

These fragments were kept by Torres Balbás in his 1930 restoration as non-structural witnesses to be interpreted during future interventions. These findings included the upper remains of a couple of rafters of white poplar wood (Populus alba) formed by logs and by a double false collar tie embracing them (Fig. 16), together with a fragment of their related timber wall plate. They have been consistently carbon-14 dated to within $1280-1400 \mathrm{AD}$ with a $95.4 \%$ probability, including a more precise dating bracket defined 
as1290-1320 AD with a 68.2\% probability (Uppsala Universitet 2014).

Surprisingly, while Torres Balbás did not mention these important findings in his writings, he nevertheless decided to keep them. Additionally, nothing was mentioned in either his restoration intervention diary (Diario de Obras), a very detailed account of his restoration work in the Alhambra from 1923 to 1936 and published at the end of his career (1969), or in the article he wrote focusing on his restoration (1945). This was probably due to his uncertainty regarding whether they were Nasrid elements or had proceeded from later interventions. Roof structures of that typology, made by very humble logs serving as rafters, were a common solution in Nasrid carpentry during the 13th and 14th centuries. This has been demonstrated in the Palace of Genil (Alcázar Genil), built in 1218 during the previous Almohad rule, and in the previously mentioned Royal Hall of St. Dominic, both in Granada (Almagro Gorbea and Orihuela Uzal 1995, 1997).

As shown in Fig. 17, the restitution of the original Nasrid roof structure of the Oratory was based on a constructive interpretation of these preserved fragments and on a site survey of the areas of their support over the walls (Artyco 2015).

The cut found on the lower end of the bestpreserved rafter was interpreted as a support for a missing shorter rafter that would have formed the roof's eaves, a characteristic element of Nasrid architecture (Artyco 2015).

The removal of the modern roof structure also allowed for a careful constructive analysis of the external side of the inner timber framework. The outcome was the discovery of an unknown-to-date first-design version of this structure.

As shown in Fig. 18, the external side of the upper horizontal plane (almizate) of the framework exhibits an initial conception of a regular pattern of alternate octagons that would have supported the decorative eightpoint star motifs (Rodríguez Trobajo 2014). This regular pattern, conceived as a grid, is formed by successive collar ties assembled orthogonally to the noggings.

Then, a series of smaller wedges were nailed to the four corners of the squared spaces of this grid, forming the abovementioned octagons. The current second and

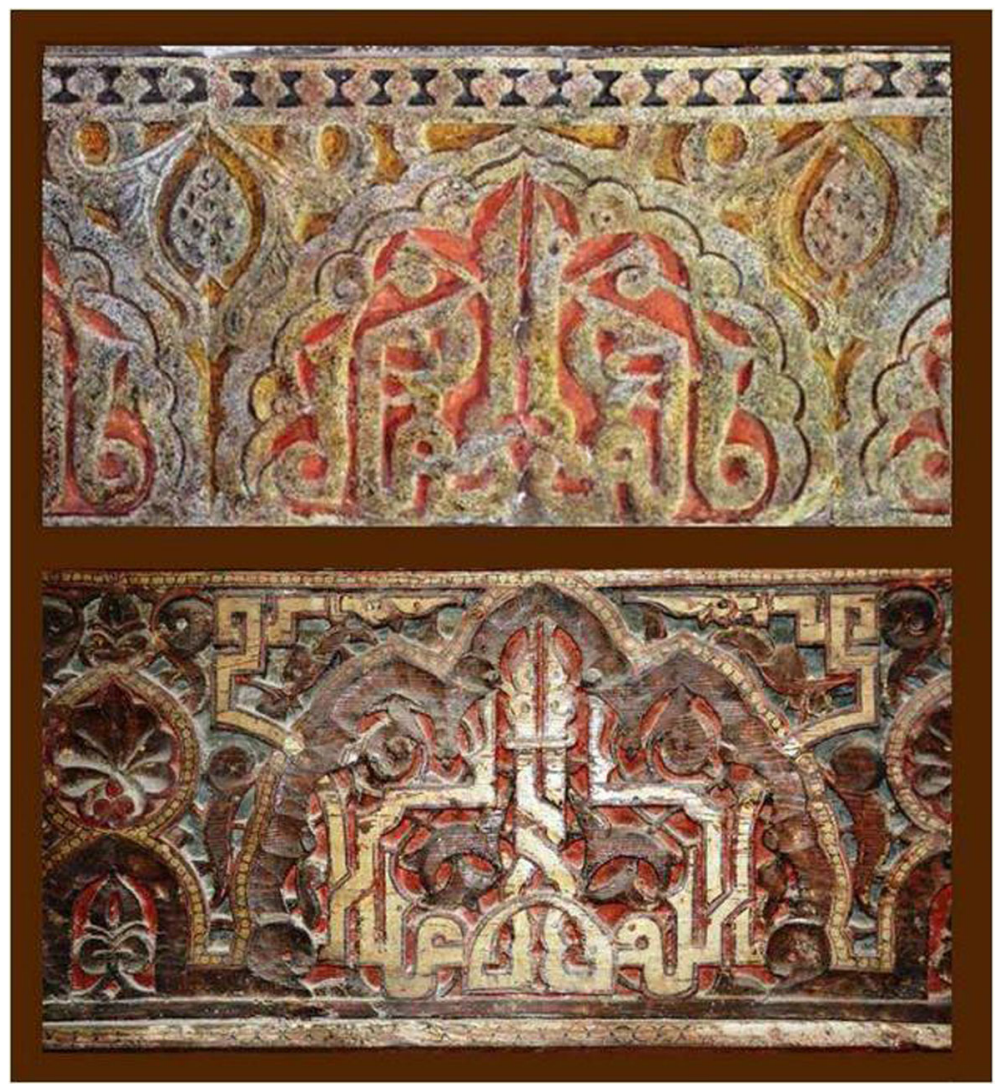

Fig. 20 Analogies between the decorative epigraphs on the Oratory's wooden frieze (above) and the wooden ceiling of the Plaster Hall (Salón del Yeso) in the Royal Palaces of Seville (below) (Source: Nuere Matauco 2014) 
definitive Nasrid design of the almizate that includes a large central octagon at its centre is clearly apparent on the internal side of this grid. A diagonal nogging defining one of the sides of this central octagon can be identified in Fig. 18 by looking through one of the square spaces of this grid (2nd row from the bottom, 2nd column from the left) (Rodríguez Trobajo 2014, 3).

This first constructive version is almost identical to the existing version of the decorated timber framework of the Painting House, which is also located in the Partal Palace and is also attributed to Yusuf I (1333-1354) (Wulff Barreiro 2012).

The discovery of new epigraphic and decorative motifs was an additional key finding. An epigraphic inscription has been recovered on the upper board (alicer) of the timber frieze (arrocabe) covering the wall plate that supports the decorated timber frame. The inscription bears a surah from the Holy Quran, a Muslim religious verse (Fig. 19, above). The lower part of this timber frieze, decorated with epigraphic and vegetal motifs (Fig. 19, below), has revealed the remains of pigments from the original Nasrid painted decorations (Artyco 2015).

Finally, a comparative study was undertaken on the decorative programme, painting techniques and pigments utilised on this timber frieze (Fig. 20, above), with similar motifs having been preserved on the wooden ceiling of the Plaster Hall (Salón del Yeso) in the Royal Palaces of Seville (Fig. 20, below). Although the fabric of this palace was finalised during the last decade of the 12th century under the previous Almohad dynasty, its wooden ceiling was built during the same period as the Oratory's timber framework under the rule of the Christian kingdom of Castille. This provides evidence of the intense exchange of craftsmen, ideas and techniques over the 14th century between the Nasrid kingdom of Granada and its ally-during that period-the Christian kingdom of Castille (Nuere Matauco 2014, 19; Manzano Martos 1999, 71; Tabales Rodríguez 2004, 46; Blasco López et al. 2009, 203). The dendrochronology dating tests applied to several samples taken from the decorated timber framework revealed the very precise date of the winter of 1332-1333 for the timber cut for its elements.

This dating has consistently proven an earlier conception and construction date of the Oratory of the Partal Palace, which would have been initiated by the sultan Isma'il I (1314-1325), rather than the previously widely accepted date that gave the attribution to Yusuf I (13331354), who instead would have finalized the work.

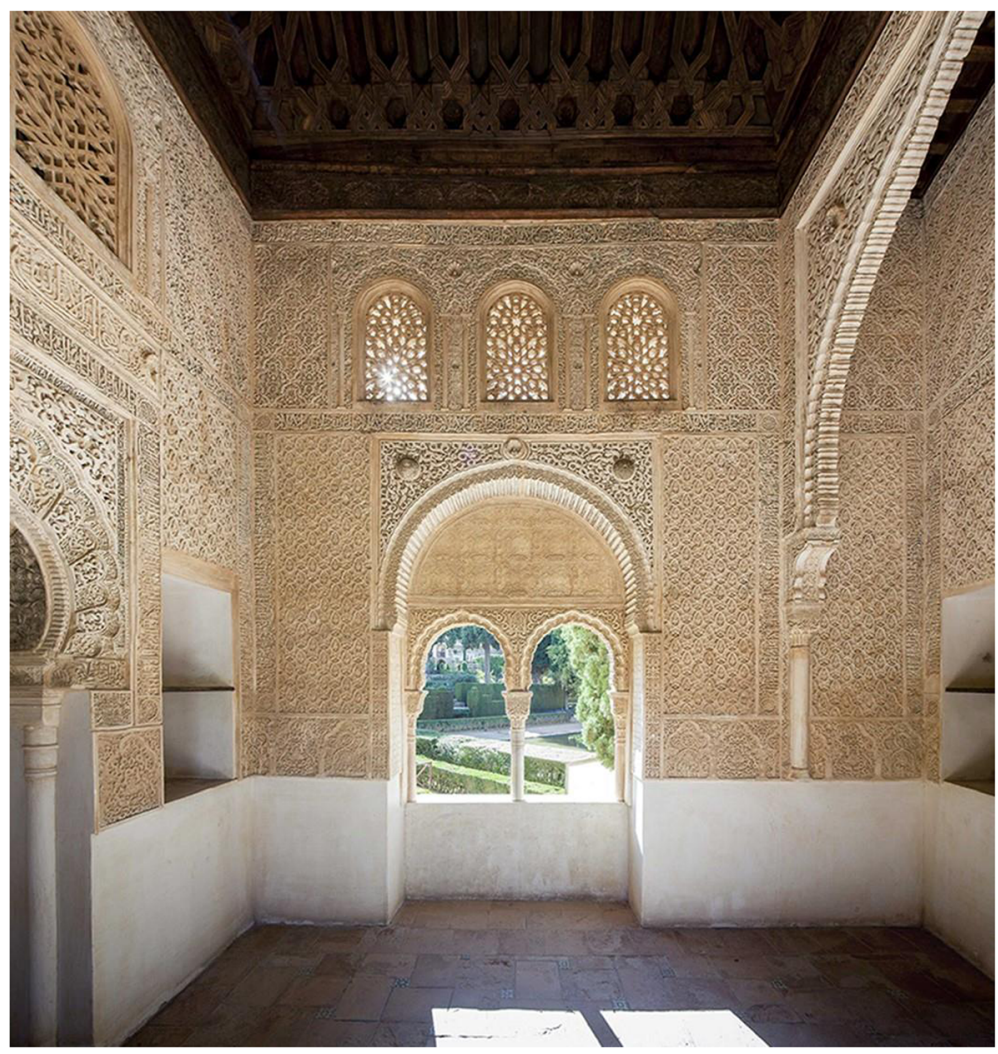

Fig. 21 Inner space of the Oratory facing the Partal gardens. Decorated plasterwork after the last restoration. Above, the restored timber framework (Source: Artyco 2015) 
(Uppsala Universitet, the Angström Laboratory / Tamdem Laboratory 2014; Rodríguez Trobajo 2014). The time lapse between these two sultans (1325-1333) was characterised by political instability and violence in the Nasrid court, so it would have been very unlikely that this difficult context would have allowed for the conception of the Oratory and the beginning of its construction. This consistent earlier dating has implied the necessity of an entirely new consideration of the phases of the building interventions in the Partal Palace. Future research should be undertaken to deepen our understanding of this unique palatine structure in the Alhambra (Fig. 21).

\begin{abstract}
Acknowledgements
This restoration, awarded with the Europa Nostra Grand Prix 2019, was cofunded by the Regional Government of Andalucía and the World Monuments Fund (WMF). I would like to express my gratitude to the Conservation Department of the Council of the Alhambra for their ongoing support for the development of this restoration and for the research that has been derived from it. I would also like to thank the restoration company Artyco for their high-quality restoration work, professional commitment and interest in collaborating with this ongoing research. I would like to acknowledge and to appreciate the collaboration and professional engagement of Mr. Miguel Castillo, the quantity surveyor who supported my role as the Director of the Restoration in his role as the Director of Execution. Additionally, I would like to highlight the support of Dr. Enrique Nuere, the architectural carpentry consultant for the duration of the restoration, who is considered the most prestigious expert in Spanish medieval carpentry and had been my PhD supervisor until a decade ago. Finally, I would like to give a special acknowledgement to Mrs. Melina Guirnaldos, architect co-founder and co-partner of $W+G$ architects, for her essential contribution over the 15 years that the restoration of and our research work on the Oratory have been developed. The exceptional research findings from this restoration have been extensively disseminated in European, Spanish and British academic forums and news media, in academic lectures and on the institutional social media networks of Europa Nostra, Hispania Nostra, Cardiff University and the World Monuments Fund organisations. It was recently highlightedin an international exhibition focusing on the awarded Spanish Europa Nostra and Hispania Nostra preservation works held at Tongji University (Shanghai, China) in November 2020.
\end{abstract}

\section{Author's contributions}

This article is authored by a single author who has contributed to all aspects of this research. The author(s) read and approved the final manuscript.

\section{Funding}

The research analysed in this article was based on the data generated by a series of prelimary reports, technical project and building restoration commissioned by the Council of the Alhambra and Generalife to the Author of the present article.

\section{Availability of data and materials}

The data that support the findings of this study are available from The Council of the Alhambra and Generalife (Regional Government of Andalucia, Spain), but restrictions apply to the availability of these data, which were used under license for the current study, and so are not publicly available. Data are however available from the authors upon reasonable request and with permission of The Council of the Alhambra and Generalife.

\section{Declarations}

Competing interests

The author declare that he has no competing interests.
Received: 15 December 2020 Accepted: 30 March 2021

Published online: 07 May 2021

\section{References}

Almagro Gorbea, Antonio, and Antonio Orihuela Uzal. 1995. El Cuarto Real de Santo Domingo de Granada. In Casas y Palacios de al-Andalus. Siglos XII y XIII. Colección El Legado Andalusí, 241-253. Barcelona: Lundwerg.

Almagro Gorbea, Antonio, and Antonio Orihuela Uzal. 1997. Propuesta de intervención en el Cuarto Real de Santo Domingo (Granada). Loggia, Arquitectura y Restauración, no. 4: 22-29.

Artyco. 2015. Obra de Rehabilitación de la Cubierta del Oratorio del Partal y Casa de Astasio de Bracamonte. Alhambra de Granada, I-II. In Final Report for the Restoration of the Roofs of the Oratory of Partal palace and the House of Astasio de Bracamonte. Alhambra of Granada. Granada: Patronato de la Alhambra y Generalife, Consejería de Cultura de la Junta de Andalucía, World Monuments Fund.

Blasco López, Francisco Javier, Francisco Javier Alejandre Sánchez, and Juan Jesús Martín del Río. 2009. Evolución de las yeserías de los Patios del Yeso y del Sol del Real Alcázar de Sevilla a través de las fuentes escritas, reforzadas por ensayos de caracterización. [Evolution of the Plasterwork Decoration of the Plaster and the Sun Courtyards of the Royal Palace of Seville through the Written Sources, Reinforced with Characterisation Tests]. In Proceedings of the 6th National Conference on Construction History, ed. Santiago Huerta et al., 201-209. Madrid: Instituto Juan de Herrera.

Contreras, Rafael. 1878. Estudio descriptivo de los monumentos árabes de Granada, Sevilla y Córdoba, ó sea, la Alhambra, el Alcázar y la Gran mezquita de occidente [Descriptive Study of the Arabic Monuments of Granada, Seville and Cordoba, that is, the Alhambra, the Alcazar and the Great Mosque of Occident]. Granada: Imprenta y litografía de A. Rodero.

Fernández-Puertas, Antonio. 1997. The Three Great Sultans of al-Dawla al-Isma 'Iliyya al-Nasriyya who Built the Fourteenth-century Alhambra: Isma'il I, Yusuf I, Muhammad V. Journal of the Royal Asiatic Society 7 (1): 1-25.

Jones, Owen, and Pascual de Gayangos. 1842. Plans, Elevations, Sections, and Details of the Alhambra. London: Owen Jones.

Jones, Owen, and Jules Goury. 1845. Details and Ornaments from the Alhambra. London: Owen Jones.

Manzano Martos, R. 1999. Los Palacios. La Arquitectura Almohade en Sevilla. TThe Palaces. The Almohad Architecture in Seville]. In Sevilla Almohade, ed. M.V. Piechotta and A. Tahiri, 63-75. Seville-Rabat: Fundación de las Tres Culturas del Mediterráneo, Universidad de Sevilla, Junta de Andalucía y Ayuntamiento de Sevilla.

Nuere Matauco, Enrique. 2014. La Restauración del Oratorio del Partal y de la Casa de Astasio de Bracamonte. Informe sobre la Intervención en la Armaduras de cubierta y el techo de lazo del Oratorio [The Restoration of the Oratory of the Partal Palace and the House of Astasio de Bracamonte. Intervention Report about the Timber Structures and the Interlaced Flat Ceiling]. Granada: The Alhambra and Generalife council, Cultural Department of the Regional Government of Andalucía.

Parra Crego, Emilia. 2014. Identificación de maderas en el artesonado del Oratorio del palacio de la Alhambra (Granada) [Wood Identification in the Timber Framework of the Oratory of the Palace of the Alhambra (Granada)]. Madrid: Larco Química y Arte S.L.

Prieto Moreno, F. 1968. Restoration project of the oratory of Partal. In APAG: Plan n.2493; n. inventory 2707. Detail of an existing column of plaster and wood on both jambs of the twin windows. In APAG: Plan n.2494; n. inventory: 2708. Project of a new central column supporting the twin arches of the windows. Granada: Patronato de la Alhambra y Generalife.

Rivera Blanco, J. 2013. Torres Balbás y la «restauración moderna y científica» en España: un restaurador de nivel internacional. [Torres Balbás and the Modern and Scientific Restoration in Spain: An Internationally Renowned Preservationist. ]. In Leopoldo Torres Balbás y la restauración científica: ensayos, ed. M. del Mar Villafranca Jiménez and R.F.-B. Casares, 289-316. Granada: Patronato de la Alhambra y Generalife, Consejería de Cultura de la Junta de Andalucía.

Rodríguez Trobajo, Eduardo. 2008. Procedencia y uso de madera de pino silvestre y pino laricio en edificios históricos de Castilla y Andalucía. [Provenance and Use of Scots Pine and Larch Pine Woods in Historic Buildings of Castille and Andalucía]. Arqueología de la Arquitectura, no. 5, 33-53.

Rodríguez Trobajo, E. 2014. Datación dendrocronológica del Oratorio en el Partal de la Alhambra [dendrochronology dating of the oratory in the Partal palace of the Alhambra]. Madrid: Instituto Nacional de Investigación y Tecnología Agraria y Alimentaria - Centro de Investigación Forestal.

Tabales Rodríguez, M.Á. 2004. El Alcázar de Sevilla. Primeros estudios sobre estratigrafía y evolución constructiva [the Alcázar of Seville. First studies on 
stratigraphy and constructive evolution]. Seville: Consejería de Cultura de la Junta de Andalucía y Patronato del Real Alcázar de Sevilla.

Torres Balbás, Leopoldo. 1945. El Oratorio y la Casa de Astasio de Bracamonte en el Partal de la Alhambra. The Oratory and the House of Astasio of Bracamonte in the Partal palace of the Alhambra.]. Al-Andalus X, Crónica Arqueológica de la España Musulmana XVII, 112-129.

Torres Balbás, Leopoldo. 1959. Cronología de las construcciones de la Casa Real de La Alhambra. [Chronology of the Constructions of the Royal House of the Alhambra.]. In Al-Andalus XXIV, Crónica Arqueológica de la España Musulmana XLV: 52-62, 402-403.

Torres Balbás, Leopoldo. 1969. Diario de las Obras en la Alhambra: 1930-1936. [Site Diary of the Preservation Works Undertaken in the Alhambra: 19301936]. Cuadernos de la Alhambra, no. 5, 75-77.

Uppsala Universitet, the Angström Laboratory / Tamdem Laboratory. 2014. Result of Carbon-14 dating of wood from the oratory of the Partal palace. Granada and Uppsala: Patronato de la Alhambra y Generalife, Consejería de Cultura de la Junta de Andalucía, Uppsala Universitet.

Wulff Barreiro, Federico. 2005. Informe de documentación histórica de intervenciones en el Oratorio del Partal de la Alhambra, como documentación previa para proyecto de intervención en el inmueble [Report of Historical Documentation on Interventions in the Oratory of the Partal Palaceof the Alhambra, as a Preliminary Documentation for an Intervention Project in the Building]. Granada: Patronato de la Alhambra y Generalife, Consejería de Cultura de la Junta de Andalucía.

Wulff Barreiro, F. 2007. Informe de Actuaciones para Proyecto de Restauración en el Oratorio del Partal de la Alhambra, Granada [report of interventions for the restoration project of the oratory of the Partal of the Alhambra, Granada]. Granada: Patronato de la Alhambra y Generalife, Consejería de Cultura de la Junta de Andalucía.

Wulff Barreiro, Federico. 2011. Origen y Evolución de la Carpintería de Armar Hispano-Musulmana. [Origin and Evolution of the Hispano-Muslim Carpentry] PhD diss., Universidad Politécnica de Madrid. http://oa.upm.es/56435/

Wulff Barreiro, F. 2012. Proyecto de Ejecución de Restauración de la Armadura del Oratorio del Partal y Casa de Astasio de Bracamonte. In Rehabilitación de las Cubiertas [technical project for the restoration of the timber framework of the oratory of the Partal Palaceand the house of Astasio of Bracamonte. Repair intervention on the roofs]. Granada: Patronato de la Alhambra y Generalife, Consejería de Cultura de la Junta de Andalucía.

\section{Publisher's Note}

Springer Nature remains neutral with regard to jurisdictional claims in published maps and institutional affiliations.

\section{Submit your manuscript to a SpringerOpen ${ }^{\circ}$ journal and benefit from:}

- Convenient online submission

- Rigorous peer review

- Open access: articles freely available online

- High visibility within the field

- Retaining the copyright to your article

Submit your next manuscript at $\boldsymbol{\nabla}$ springeropen.com 